\section{jati \\ JUANALAKUNTANSI \\ C TERAPAN INDDNESIA}

Jurnal Akuntansi Terapan Indonesia Vol 3 No 2 Hal 40-54 October 2020

\title{
Analisis Penerapan Islamic Social Reporting dan Tata Kelola Lembaga Keuangan Mikro Syariah dalam Mendorong Mobilitas Sosial Nasabah
}

\author{
Rizal Yaya*1, Kartika Dewi Purnami²
}

Affiliation:

Universitas Muhammadiyah

Yogyakarta, Indonesia

*Correspondence:

r.yaya@umy.ac.id

This Article is Avalilable in:

https://journal.umy.ac.id/index.

php/jati/article/view/9163

DOI:

https://doi.org/10.18196/jati.030226

\section{Citation:}

Yaya, R., \& Purnami, K. (2020). Analisis Penerapan Islamic Social Reporting dan Tata Kelola Lembaga Keuangan Mikro Syariah dalam Mendorong Mobilitas Sosial Nasabah. Jati: Jurnal Akuntansi Terapan Indonesia, 3(2), 4054.

\section{Article History}

Received:

20 July 2020

Reviewed:

06 Agustus 2020

Revised:

14 October 2020

Accepted:

20 October 2020

Topic Article:

Akuntansi Syariah

\begin{abstract}
:
This research aims to evaluate the implementation of Islamic Social Reporting (ISR) and governance in the Islamic microfinance institutions to encourage social mobility. The object of this study is Islamic Micro Finance (BMT) BIF and Islamic Rural Bank (BPRS) BDW. This research used a qualitative descriptive method. Based on the analysis, both institutions provide funding for their customers based on Islamic contracts and mostly for working capital. The financing procedure was through the collection of customer's identity, conducting surveys and contract signing. The installment to BMT BIF and BPRS BDW was made by the customers in two ways. Social activities in both institutions are relatively similar but social activity reporting format is different. BMT BIF social responsibility activities are reported specifically in the BMT Annual General Meeting (RAT), meanwhile the BPRS BDW has not made specific social responsibility reporting for their Annual General Meeting. From financing and social responsibility, both institutions have been able to assist the movement of social mobility in society, especially in customers. Regarding ISR compliance reporting for both institutions, the BMT BIF has met 70\%-80\% compliance, while BPRS BDW 50\% compliance.
\end{abstract}

Keywords: Financing, Social Responsibility, Islamic Social Reporting (ISR), Social Mobility, Poverty

\begin{abstract}
Abstrak:
Penelitian ini bertujuan untuk mengevaluasi penerapan Islamic Social Reporting (ISR) dan tata kelola di lembaga keuangan mikro syariah untuk mendorong mobilitas sosial. Objek penelitian ini yaitu Islamic Micro Finance (BMT) BIF dan Bank Perkreditan Rakyat Syariah (BPRS) BDW. Penelitian ini menggunakan metode deskriptif kualitatif. Berdasarkan analisis, kedua lembaga tersebut memberikan pendanaan kepada pelanggannya berdasarkan akad syariah dan sebagian besar untuk modal kerja. Prosedur pembiayaan melalui pengumpulan identitas nasabah, melakukan survei dan penandatanganan kontrak. Angsuran BMT BIF dan BPRS BDW dilakukan oleh nasabah dengan dua cara. Kegiatan sosial di kedua panti tersebut relatif sama nanun format pelaporan kegiatan sosial berbeda. Kegiatan tanggung jawab sosial BMT BIF dilaporkan secara khusus dalam Rapat Umum Tahunan (RAT) BMT, sedangkan BPRS BDW belum membuat laporan tanggung jawab sosial khusus untuk Rapat Umum Tahunannya. Dari pembiayaan dan tanggung jawab sosial, kedua lembaga tersebut telah mampu membantu pergerakan mobilitas sosial di masyarakat, khususnya nasabah. Terkait pelaporan kepatuhan ISR kedua institusi, BMT BIF telah memenuhi kepatuhan 70\% -80\%, sedangkan kepatuhan BPRS BDW 50\%.
\end{abstract}

Kata Kunci: Pembiayaan, Tanggung Jawab Sosial, Islamic Social Reporting (ISR), Mobilitas Sosial, Kemiskinan 


\section{PENDAHULUAN}

Lembaga keuangan mikro saat ini semakin banyak berdiri baik di daerah- daerah kecil maupun perkotaan dan provinsi. Pada tahun 2014, Otoritas Jasa Keuangan (OJK) mencatat 600 ribu lebih Lembaga Keuangan mikro yang berdiri di Indonesia (Republika, 2014). Lembaga Keuangan Mikro tidak hanya berdiri berdasarkan prinsip konvensional, saat ini juga banyak berdiri lembaga keuangan Syariah. Indonesia sebagai Negara yang sebagian besar ditempati oleh mayoritas masyarakat muslim diharapkan dapat menjadi satu negara yang dapat menggerakkan ekonomi Syariah termasuk Lembaga Keuangan Mikro Syariah (LKMS). LKMS ini mengutamakan pelayanan jasa keuangan dengan pemberian pembiayaan dan diikuti dengan pemberdayaan terhadap usaha mikro yang diberikan pembiayaan (Baskara, 2013). Saat ini, LKMS di Indonesia terdiri dari Baitul Maal Wat Tamwil (BMT) atau koperasi syariah dan Bank Perkreditan Rakyat Syariah (BPRS).

Hardi (2013) mengungkapkan bahwa LKMS dianggap mampu mengatasi permasalahan kesulitan masyarakat dalam mengakses lembaga keuangan yang ada. Hal ini disebabkan karena BMT dekat dengan masyarakat menengah kebawah dan dengan akses yang baik (Yusuf, 2014). Di Indonesia, kemiskinan di masyarakat masih cukup tinggi, salah satunya di Daerah Istimewa Yogyakarta. Berdasarkan pada BPS 2016 angka kemiskinan keseluruhan DIY 13,20\% angka ini lebih besar dari presentase total angka kemiskinan nasional yaitu 11,13\% (BPS, 2017). Adanya permasalahan ini menyebabkan ketimpangan sosial di masyarakat. Masih adanya permasalahan tersebut membutuhkan gerakan yang membantu setiap individu/ masyarakat dalam melakukan pergerakan mobilitas sosial. Dengan adanya bantuan tersebut masyarakat strata bawah diharapkan dapat terdorong untuk bisa meningkatkan taraf hidup mereka dan selanjutnya menaikkan strata hidup ke yang lebih tinggi yang disebut dengan mobilitas sosial (Wahyuni, 2015).

Pergerakan mobilitas sosial dapat dilakukan oleh individu itu sendiri maupun dorongan dari saluran-saluran tertentu seperti lembaga sosial, ekonomi, pendidikan, dan keuangan, salah satunya LKMS yang diharapkan menjadi wadah untuk penghimpunan dana masyarakat menengah kebawah (Latif, 2016). Menurut Undang-undang No.1 tahun 2013 Lembaga Keuangan Mikro merupakan sebuah lembaga keuangan yang khusus didirikan untuk masyarakat mikro dengan memberikaan jasa pengembangan usaha dan pemberdayaan masyarakat. Jasa pembiyaan diberikan kepada anggota lembaga keuangan mikro maupun kepada masyarakat yang membutuhkan dana sebagai pengembangan usahanya. Selain itu juga ada pemberian jasa konsultasi dan pendampingan secara gratis untuk pengembangan usaha yang dilakukan sehingga LKMS tidak hanya untuk mengejar keutungan (Baskara, 2013). BMT dan BPRS sebagai LKMS memiliki akses kepada masyarakat menengah kebawah diharapkan dapat menjadi pendorong pergerakan mobilitas sosial di masyarakat (Zuraya, 2016). Namun, pada saat ini belum banyak diketahui praktik tanggung jawab sosial yang dilakukan oleh lembaga keuangan syariah (Erwanda, 2012). Penelitian ini menggali bagaimana praktik tata kelola LKMS dalam mendorong mobilitas sosial nasabah dan melaporkannya dalam perspektif Islamic social reporting. Kontribusi penelitian ini terletak pada perbandingan langsung antara praktik BMT dan di BPRS

\section{Baitul Maal Wat Tamwil (BMT)}

BMT sebagai lembaga keuangan mikro berbasis syariah dan berlandaskan pada ajaran agama Islam. Dalam hal perizinan BMT beroperasi setelah mendapat izin dari Kemetrian Koperasi dan UKM Republik Indonesia. BMT secara etimologis terbagi menjadi 2 arti yaitu Baitul Maal yang artinya rumah uang dan Baitul tamwil yang artinya rumah pembiayaan. Baitul Maal atau rumah harta berarti adanya pengumpulan dana yang dilakukan 
dalam lembaga ini yang berasal dari kegiatan sosial yang dilakukan berupa infaq, zakat, dan Sadaqah, serta dalam hal ini adanya pembiayaan yang diberikan sesuai dengan prinsip bagi hasil yang sesuai dengan ketentuan tanpa adanya prinsip bunga atau keinginan untuk mendapatkan keuntungan yang diperoleh atas pembiayaan tersebut (Baskara, 2013). BMT saat ini sudah mulai berkembang dibeberapa daerah maupun perkotaan salah satunya yaitu di DI.Yogyakarta sebanyak 42 Unit BMT berdiri.

\section{BPRS}

Bank Pembiayaan Rakyat Syariah (BPRS) merupakan salah satu bentuk perbankan dengan skala mikro yang lebih berfokus pada pembiayaan yang dioperasikan sesuai dengan ajaran Islam. Bank Pembiayaan Rakyat Syariah beroperasi sama dengan Bank Pembiayaan Konvensional hanya saja pada BPRS segala kegiatan keuangan dan program-program yang dijalankan didalam lembaga keuangan tersebut harus sesuai dengan prinsip-prinsip syariah. BPRS sebagai Lembaga Keuangan Mikro Berbasis Syariah mempunyai Dewan Pengawas Syariah sebagai pengawas lembaga keuangan tersebut untuk menilai dan memberikan masukan terkait apakah prosedur yang dijalankan oleh lembaga keuangan sudah sesuai dengan ketentuan Syariah (Yaya dkk, 2013). BPRS dapat berdiri dan dapat beroperasi setelah adanya persetujuan dari Otoritas Jasa Keuangan (OJK) sebagai regulator perbankan di Indonesia. BPRS dalam operasional kegiatan usahanya diantaranya melakukan penghimpunan dana berupa tabungan, deposito dan menyediakan pembiayaan sesuai dengan prinsip-prinsip syariah (Buchori, 2003). Bank Pembiayaan Rakyat Syariah sudah banyak berdiri di Indonesia termasuk salah satunya di kota Yogyakarta sudah terdapat 11 BPRS yang terdaftar di OJK pada Januari 2015.

\section{Mobilitas Sosial}

Perubahan strata sosial dalam mobilitas sosial cenderung bisa diterapkan pada masyarakat terbuka, karena pada masyarakat terbuka lebih memungkinkan untuk terjadi perubahan strata sedangkan pada masyarakat yang cenderung tertutup akan sulit pula untuk terjadinya adanya perubahan strata. Mobilitas sosial dapat terjadi melalui beberapa faktor diantaranya ada faktor internal yaitu dari dalam diri individu seseorang seperti keinginan untuk mengubah diri dalam mengubah standar hidup, cara berfikir lebih maju dan lain sebagainya. Selain itu ada pula faktor eksternal yang memengaruhi mobilitas sosial diantaranya adanya lembaga pendidikan, lembaga keuangan termasuk lembaga keuangan syariah mikro yang memberikan pembiayaan kepada para anggotanya maupun masyarakat untuk pencapaian tujuan syariah (Finarti, 2015). Pada beberapa faktor-faktor tersebut dapat membantu masyarakat untuk melakukan mobilitas sosial, perubahan mobilitas melalui beberapa hal diatas dapat terjadi dalam jangka waktu singkat maupun dalam jangka waktu Panjang.

Faktor pendorong mobilitas sosial yang dapat dilakukan melalui adanya faktor eksternal yaitu Lembaga Keuangan Syariah Mikro salah satunya, dapat dikatakan bahwa Lembaga Keuangan Mikro membantu dalam pergerakan mobilitas sosial karena didalam lembaga keuangan syariah mikro sebagai salah satu lembaga keuangan yang memiliki tanggung jawab kepada anggotanya maupun masyarakat dalam memberikan pembiayaan (Fitria \& Hartanti, 2010).

\section{METODE PENELITIAN}

Jenis penelitian yang akan dilakukan ini menggunakan jenis penelitian kualitatif Deskriptif studi kasus membanding praktik tata kelola dan pengungkapan Islamic Social 
Reporting untuk meningkatkan mobilitas vertikal nasabah di kedua LKMS. Penggunaan metode studi kasus agar memungkinkan peneliti melihat kedua objek penelitian secara lebih mendalam untuk mendapatkan informasi yang akurat dan andal. Penelitian ini dilakukan secara sistematis yaitu dimulai dari proses pengamatan, pengumpulan data, analisis informasi, hasil penelitian dan pelaporan hasil atas penarikan kesimpulan yang diperoleh dari informasi-informasi yang didapat selama proses penelitian (Ibrahim, 2015).

Data primer yang digunakan dalam penelitian ini diperoleh dari proses penelitian yaitu dengan melakukan interview kepada para informan langsung, tidak hanya melihat pada hasil data yang sudah ada sebelumnya. Interview dilakukan kepada beberapa pihak diantaranya marketing terkait dengan pembiayaan yang behubungan langsung dengan nasabah, bagian pelaporan terkait dengan sistem pelaporan dan nasabah penerima pembiayaan dan tanggung jawab sosial di lembaga keuangan mikro tersebut.

Data sekunder merupakan teknik pengumpulan data yang dilakukan oleh peneliti dengan menggunakan laporan tahunan maupun data yang sudah ada sebelumnya dan menggunakan Laporan Keuangan BMT BIF dan BPRS BDW 2013-2015, Laporan Kegiatan Tanggung jawab sosial yang dilakukan BMT BIF dan BPRS BDW tahun 2013-2015, catatancatatan, dan data-data lain yang dapat membantu dalam menyesuaikan antara data yang ada dengan realita yang terjadi dimasyarakat akan tanggung jawab sosial dan pembiayaan yang dilakukan oleh BMT BIF dan BPRS BDW.

Pada penelitian ini studi pustaka diperoleh melalui teknik dokumentasi yang merupakan teknik pengumpulan data dengan mempelajari dan melihat review dari jurnal ilmiah, buku, artikel, pelaporan, dan catatan-catatan yang berkaitan dengan pembiayaan dan tanggung jawab sosial yang dilakukan lembaga keuangan berbasis syariah dan pembiayaan yang diberikan, serta penerapan Islamic Social Reporting. Selain itu dengan adanya studi pustaka akan lebih membantu pengembangan dari penelitian ini.

Studi Lapangan merupakan metode untuk memperoleh data yang dilakukan dengan pengamatan secara langsung dan lebih mendalam terhadap suatu objek sebagai suatu instrument penelitian. Studi lapangan dilakukan selama bulan September sampai dengan Desember 2016 dengan menggunakan berbagai instrumen berikut:

Jenis penelitian yang digunakan dalam penelitian ini yaitu wawancara semiterstruktur, pada metode wawancara semi terstruktur ini peneliti melakukan wawancara dengan cara peneliti menyiapkan beberapa pertanyaan kunci yang akan dijadikan panduan untuk jalannya proses tanya jawab pada saat wawancara. Pada wawancara semi-terstruktur ini peneliti dapat mengembangkan kembali pertanyaan kunci yang telah dimiliki pada saat proses tanya jawab dilakukan (Moleong, 2016). Berikut adalah isu kunci yang ditanyakan kepada para informan.

Tabel 1: Isu Kunci Pertanyaan pada Informan

\begin{tabular}{|c|c|}
\hline Staff BMT BIF/BPRS BDW & $\begin{array}{c}\text { Nasabah/ Anggota Binaan BMT BIF/ } \\
\text { BPRS BDW }\end{array}$ \\
\hline $\begin{array}{l}\text { - } \quad \text { Bentuk Pembiayaan yang diberikan } \\
\text { - } \quad \text { Proses pelaksanaan pembiayaan } \\
\text { - } \\
\text { - } \text { distem pengawasan pembiayaan yang sudah } \\
\text { - } \quad \text { Bentuk tanggung jawab sosial } \\
\text { - } \quad \text { Lama waktem pelaporan tanggung jawab sosial } \\
\text { - } \quad \text { Pembiayaan yang diperoleh nasabah } \\
\text { terhadap pelaporan keuangan }\end{array}$ & $\begin{array}{ll}\text { - } & \text { Proses Pengajuan pembiayaan } \\
\text { - } & \text { Bentuk pembiayaan yang diterima } \\
\text { - } & \text { Proses pelaksanaan pembiayaan } \\
\text { - } & \text { Sistem pengawasan yang dilakukan pihak } \\
\text { - } & \text { Lembaga keuangan } \\
\text { - } & \text { Manfaat pembiayaan yang diperoleh. }\end{array}$ \\
\hline
\end{tabular}


Observasi dalam penelitian ini dilakukan sebagai sumber bukti pendukung dari hasil wawancara, dengan adanya observasi ini dilakukan dengan peneliti mengamati objek secara langsung. Observasi ini menggunakan observasi partisipasi pasif, yaitu peneliti melakukan pengamatan dengan mendatangi langsung tempat kegiatan dijalankan tanggung jawab sosial dan pembiayaan yang diberikan oleh BMT BIF dan BPRS BDW, tetapi tidak terlibat dalam kegiatan tersebut secara langsung.

Dokumentasi merupakan dokumen pendukung dari data-data primer yang akan digunakan, pada dokumentasi ini berupa data-data berbetuk tulisan seperti memo, catatancatatan, pengumuman dan lain lain. Studi dokumentasi ini digunakan untuk melengkapi metode wawancara dan observasi dalam suatu strategi penelitian kualitatif.

Reduksi data merupakan proses pemilihan yang dilakukan dengan melakukan pemusatan dan penyederhanaan, pengabstrakan dan transformasi data yang siap diolah yang muncul dari catatan-catatan tertulis mengenai BMT BIF dan BPRS BDW yang diperoleh selama berlangsung penelitian. Reduksi pada penelitian ini dilakukan dengan menajamkan, menggolongkan, mengarahkan dan membuang yang tidak perlu serta mengorganisasikan data sehingga dapat ditarik kesimpulan akhir. Peneliti melakukan reduksi data dengan cara membuat catatan lapangan atas hasil wawancara dengan informan dari BMT BIF dan BPRS BDW. Selain itu juga informan dari objek penerima pembiayaan dan tanggung jawab sosial dan pembiayaan dari BMT BIF dan BPRS BDW.

Penyajian data dalam hal ini merupakan penyajian atas sekumpulan informasi yang tersusun yang memungkinkan adanya penarikan kesimpulan pengambilan tindakan. Penyajian data dalam penelitian ini disampaikan pada teks naratif berupa catatan lapangan dan diperkuat dengan hasil pengamatan dilapangan yang akan dilakukan peneliti.

Penarikan Kesimpulan dalam penelitian ini bermaksud untuk dilakukan verifikasi atas hasil kesimpulan dari data yang diperoleh selama proses penelitian dengan melakukan analisis data agar hasil yang diperoleh lebih rinci dan terfokus dengan jelas. Kesimpulan yang di peroleh untuk menjawab tingkat kesesuaian pelaporan dengan Indeks ISR dengan melihat jumlah presentase terpenuhinya indeks ISR (Junaidi, 2015). Dinilai dari tabel pengungkapan ISR yang mengacu pada penelitian Othman et.al (2010) yang terdiri dari 6 aspek pengungkapan dan 43 item pengungkapan, pada aspek ke 2 mengenai produk dan jasa peneliti mengganti beberapa item didalamnya yang sesuai dengan produk dan jasa lembaga yang digunakan sebagai objek penelitian. Selain itu kesimpulan yang diperoleh selama penelitian dihasilkan dengan cara memikirkan kembali selama dilakukan penulisan, meninjau kembali catatan-catatan studi lapangan, dan meninjau kembali dengan teman dan pembimbing.

\section{HASIL DAN PEMBAHASAN}

\section{Tata Kelola Produk Pembiayaan}

Dari kedua LKMS yang diteliti memiliki beberapa bentuk pembiayaan yang relatif sama sesuai dengan ketentuan-ketentuan syariah. Pada lembaga BMT Bina Ikhsanul Fikri pembiayaan berdasarkan akad ada 7 jenis pembiayaan yaitu Mudharabah, Murabahah, Musyarakah, Qardlu Hasan, Hiwalah, Ijarah, dan Al-Qard dan pada BPRS Bangun Drajat Warga ada 5 jenis pembiayaan yang disediakan yaitu Mudharabah, Murabahah, ljarah, Multi Jasa, Pembiyaan Umroh yang ikut pada IMJ. Kedua lembaga keuangan mikro tersebut memiliki bentuk pembiayaan yang sudah memenuhi beberapa pembiayaan yang sesuai dengan ketentuan syariah. Dari beberapa jenis pembiayaan yang dimiliki oleh masing- masing lembaga keauangan mikro syariah tersebut pembiayaan mudharabah paling banyak diminati baik di BMT BIF maupun BPRS BDW. 
Pembiayaan yang diberikan dari kedua lembaga tersebut memiliki sasaran yang berbeda dengan adanya kriteria tertentu yang ditetapkan oleh masing-masing LKMS tersebut. Pada BMT BIF sasaran pembiayaan cenderung diberikan kepada anggota yang memang dirintis dari bawah, bahkan ada yang belum memiliki usaha diberikan pembiayaan untuk membuka usaha. Hal ini tentunya tidak lepas dari adanya pengamatan sebelum pembiayaan diberikan seperti melihat karakter dan potensi dari usaha yang akan dibiayai serta beberapa pertimbangan yang memungkinkan bagi BMT BIF ini memberikan pembiayaan dengan tepat sasaran untuk yang benar-benar membutuhkan pembiayaan. Hasil interview yang dilakukan pada salah satu nasabah loyal yang ada di BMT BIF pembiayaan diberikan pada saat nasabah tersebut belum memiliki usaha dan baru mau merintis usahanya tersebut. Selain diberikan kepada nasabah yang akan menjalankan usaha, BMT BIF juga memberikan pembiayaan mudharabah kepada para pedagang-pedagang kecil yang ada dipasar.
"Pembiayaan yang diterima untuk modal kerja, modal kerja tersebut digunakan untuk membeli dandang, nampan, cetakan untuk mencetak nata de coconya yang nantinya hasil berupa lembaran-lembaran, nanti hasil lembaran itu disetor kepengepul, Jadi disitu dari pengepulnya dibersihakan terus diiris-iris sesuai permintaan konsumen, akalu sudah dinetralkan dikemas, dikirim kegaruda Food". (NA1)

Pada LKMS, sasaran penerima pembiayaan pada BPRS BDW berbeda dengan yang ada pada BMT BIF, pada BPRS BDW cenderung pemberian bentuk pembiayaan mudharabah yang diberikan berupa modal usaha yang sudah berdiri atau berjalan namun membutuhkan modal untuk mengembangkan usaha dari para nasabah tersebut dan dapat dikatakan pembiayaan yang diberikan BPRS BDW besar untuk anggota loyalnya.

“.... Biasanya kita paling sering kalau yang sudah punya usaha, kalau yang baru memulai mendirikan usaha biasanya kita condong ke pembiayaan murabahah, yang nantinya akan digunakan untuk membeli bahan baku untuk pengembangan usaha". (B1)

Dari jawaban masing-masing intervieew pada masing-masing lembaga dari jawaban staff menunjukan bahwa pada LKMS pada BMT BIF sasaran penerima pembiayaan lebih pada nasabah yang memang memulai usahanya dari nol, dari titik bawah yang memang belum memiliki usaha dari pihak BMT BIF membantu dalam perintisan suatu usaha benar-benar dari belum mempunyai usaha hingga mampu berjalan usaha tersebut dan cenderung pemberian usaha diberikan ke usaha-usaha mikro. Sedangkan pada BPRS BDW lebih kepada nasabah yang sudah memiliki usaha yang memang dalam tahap pengembangan usaha, pihak BDW membantu dengan bentuk pembiayaan untuk modal usaha sesuai dengan kebutuhan nasabah dan cenderung lebih besar dalam pemberian pembiayaan terutama kepada para nasabah loyalnya yang dirasa tepat tentunya dengan beberapa pertimbangan didalamnya seperti melihat bagaimana trek record dari nasabah tersebut, bagaimana prospek kedepan usahanya dalam jangka panjang.

"ya karena kami sebagai pengusaha kecil butuh untuk mengembangkan usaha kami... Saya menjadi nasabah di BDW sejak 2005 berarti sudah 11 tahun, pembiayaan dari awal 5 juta sampai sekarang di BDW difasilitasi sampai 1 M". (NB1)

Pelaksanaan pembiayaan dilakukan diawali dengan adanya proses pengajuan yang dilakukan oleh masing-masing nasabah, dari hasil interview yang dilakukan proses pengajuan 
yang dilakukan sebelum menerima pembiayaan relative 9 sama. Pada BMT BIF proses pengajuan dilakukan dengan adanya beberapa hal yang harus dilakukan. Dari hasil interview memperlihatkan proses pengajuan yang sederhana yaitu pertama adanya proses administrasi yang memang menjadi suatu hal wajar yang dilakukan di beberapa lembaga keuangan, lalu pengumpulan identitas guna melihat apakah identitas calon penerima pembiayaan lembaga keuangan tersebut telah sesuai dan akan digunakan sebagai identitas penerima pembiayaan yang tentunya akan menjadi arsip di lembaga keuangan tersebut. Proses pengajuan selanjutnya yaitu survai yang biasanya dilakukan oleh masing- masing lembaga keuangan untuk melihat bagaimana tempat usaha yang akan digunakan dari nasabah tersebut untuk menjalankan usahanya apakah memungkinkan atau tidak, selain itu untuk melihat bagaimana prospek usaha tersebut apakah bisa berjalan atau tidak.

Pengajuan Pembiayaan pada BPRS BDW juga dilakukan dengan beberapa hal salah satunya yaitu bagaimana staff marketing BDW melakukan expansi dengan tujuan mencari nasabah yang membutuhkan pembiayaan. Pada BPRS BDW proses pengajuan pembiayaan yang pertama dilakukan adanya kesepakatan untuk akad yang akan digunakan, sebelum proses persetujuan akad untuk mencari nasabah dilakukan dengan 2 hal yaitu dari staff marketing BPRS BDW melakukan ekspansi dan dari pihak nasabah sendiri yang sudah mengetahui informasi mengenai BDW yang datang langsung ke BDW. Proses kesepakatan akad dilakukan sesuai dengan kebutuhan nasabah akad apa yang akan mereka pilih dari beberapa jenis akad untuk pembiayaan yang ada di BPRS BDW, untuk jenis pembiayaan modal kerja (mudharabah) untuk proses survei yang dilakukan akan lebih detail hal tersebut tentunya sangat beralasan karena untuk jenis pembiayaan mudharabah yang akan digunakan sebagai modal kerja tentunya akan bersangkutan dengan kelangsungan sebuah usaha baik untuk sekarang maupun kemungkinan berjalannya usaha dimasa datang dan laporan laba rugi serta nisbah bagi hasil dari proses usaha tersebut.

\section{Tata Kelola Pengawasan dan Pendampingan}

Selain memberikan pembiayaan dari LKMS ini melakukan pengawasan ataupun pendampingan yang dilakukan baik di pihak BMT BIF maupun BPRS BDW. Sistem pendampingan yang dilakukan di BMT BIF diberikan kepada semua nasabah yang menerima pembiayaan tidak hanya pada usaha diluar usaha yang dipasar, tatapi juga pada nasabah yang ada dipasar. Jadi setiap akhir tutup buku di lakukan pengecekan nasabah siapa-siapa saja yang belum membayarkan angsuran pembiayaan, misalkan pada salah satu nasabah penerima pembiayaan tersebut ditemukan beberapa kali tidak membayarkan angsurannya disitulah pihak BIF melakukan pembinaan/adanya pendampingan. Pembinaan ini dilakukan dengan pihak marketing mendatangi nasabah yang belum melakukan pembayaran angsuran tersebut dengan menanyakan kenapa dan apa kendalanya sehingga dalam beberapa kali tidak dapat membayarkan angsuran. Selain itu apabila permasalahan ditemukan dan bukan karena memang terjadi kesengajaan tidak melakukan pembayaran angsuran pembiayaan tersebut, maka dari pihak BMT BIF mencarikan solusi bagaimana caranya agar permasalahan tersebut selesai tanpa adanya paksaaan dari pihak BIF untuk pembayaran harus segera dilakukan. Jadi BMT BIF benar-benar melakukan pendampingan kepada masyarakat dan adanya pengawasan setelah adanya proses pemberian pembaiyaan.

Sistem pengawasan/pendampingan juga dilakukan oleh BPRS BDW yang ditugaskan pada Account Officer (AO) yang ada di BDW karena tugas AO tidak hanya mencari nasabah, melakukan pencairan tetapi dia juga bertugas untuk melakukan pengawasan serta pendampingan/pembimbingan kepada para nasabahnya. Pembinaan di BPRS ini tidak dilakukan secara terstruktur dan terjadwal melainkan dilakukan pada saat-saat tertentu saja seperti pada saat marketing/AO melewati tempat usaha dari nasabah pembiayaanya maka 
dilakukan silaturahmi ke nasabah tersebut, kemudian dibuatnya sistem rolling jadi tidak setiap saat atau pada waktu yang telah ditentukan pihak marketing/AO yang sama yang datang ketempat usaha yang sama maka dibuatlah sisitem rolling. Selain itu, dilakukan dengan menghubungi nasabah melalui telephon yang dilakukan sewaktu-waktu oleh marketing/AO sesuai dengan kebutuhan serta tujuannya. Sistem pendampingan dan pembiayaan yang dilakukan BPRS BDW lebih bersifat fleksibel, tujuan dari pendampingan dan pembinaan yang ada pada BPRS BDW yaitu untu memastikan berjalannya proses bisnis yang dijalankan pada usaha yang mendapatkan pembiayaan, kemudian melihat bagaimana perkembangan usaha kedepannya, dan berbagai alasan lainnya yang pasti untuk melihat bagaimana pembiayaan yang diberikan BDW ini benar-benar bermanfaat dengan baik.

\section{Tanggung Jawab Sosial LKMS}

LKMS sebagai lembaga syariah tidak hanya berkewajiban memberikan bantuan berupa pembiayaan saja, akan tetapi dapat memberikan suatu tindakan ataupun kegiatan berkaitan dengan kegiatan sosial kepada masyarakat yang bermanfaat untuk kemaslahatan sesama manusia (Khoirudin, 2013). Dari kedua LKMS yang telah diteliti, keduanya memiliki cara tersendiri untuk melakukan kegiatan tangggung jawab sosial kepada lingkungan sekitarnya. Bentuk tanggung jawab sosial yang diberikan masing- masing lembaga keuangan ada yang diberikan langsung seperti adanya program khusus sosial yang diberikan dengan adanya acara-acara sosial tertentu, ada pula bentuk tanggung jawab sosial yang tidak diberikan secara langsung akan tetapi dimasukan dalam suatu bentuk pembiayaan sosial.

Dalam suatu bentuk tanggung jawab sosial tentunya masing-masing lembaga keuangan memiliki perbedaan, seperti pada kedua lembaga keuangan dalam penelitian ini. Bentuk Tanggung Jawab sosial yang diberikan pada BMT BIF berupa kegiatan sosial secara langsung dan secara tidak langsung yaitu melalui pembiayaan sosial yaitu pembiayaan AlQard. Kegiatan tanggung jawab sosial yang secara langsung dilakukan oleh BMT BIF ada beberapa yang memang rutin atau pada saat hari-hari tertentu, seperti kegiatan donor darah yang memang dibuat oleh BIF di perkampungan yang ada didekat kantor pusat BIF.

Selain beberapa kegiatan sosial yang diadakan di lingkungan sekitar, BIF juga memiliki agenda khusus yang memang sudah menjadi program BIF salah satunya kegiatan menyantuni anak yatim yang dilakukan di daerah Keprakan Lor, Yogyakarta ada kegiatan jalinan kasih yang dilakukan pada saat lebaran. Kegiatan "jalinan kasih" dilakukan dengan menyantuni anak yatim piatu yang ada didaerah Keprakan Lor, selain memberikan santunan kepada anak yatim BMT BIF memiliki anggota binaan di daerah Keprakan Lor tersebut. Anggota Binaan yang dimiliki BMT BIF merupakan suatu kelompok masyarakat yang biasanya terdiri dari 10-20 orang dalam satu kelompok, dimana anggota binaan ini akan mendapatkan pelatihan, kegiatan-kegiatan yang bermanfaat termasuk ngaji lansia, serta diberikan pembiayaan sosial (AL-Qard). Anggota Binaan BIF yang menjadi objek penelitian ini yaitu anggota binaan yang ada di ds. Keprakan Lor RW 9.

Anggota Binaan yang ada di ds. Keprakan Lor memiliki kegiatan rutin yang dilakukan setiap 2 minggu sekali yaitu kegiatan ngaji khusus untuk lansia, Ngaji ini ditujukan untuk para ibu-ibu lansia yang ada di Ds. Keprakan Lor RW 8-9 yang berjumlah 70-80 orang. Ngaji disini bukan berarti kegiatan belajar mengaji Al-Qur'an atau yasinan dan lain lain, namun kegiatan ngaji disini dibuat dengan mendatangkan seorang pendongeng yang berkaitan dengan nilainilai islam seperti dongeng para nabi sehingga lebih menarik bagi para lansia. Selain kegiatan mendongeng di tempat ngaji juga ada diberikan pembelajaran mengenai terjemahan dari surat-surat seperti surat Al-Fatihah. Dikelompok ngaji tersebut juga mendapatkan pembiayaan berupa pembiayaan Al-Qard. Pembiayaan ini pertama kali diajukan oleh satu perwakilan dari lansia yang ada di Keprakan Lor RW 9 yaitu ibu Sri Wiro, beliau mengajukan 
pembiayaan yang beliau katakana sebagai pembiayaan sosial serta mengajukan programprogram untuk para lansia yang ada dikeprakan Lor. Program yang akhirnya diberikan oleh BIF sendiri yaitu Ngaji untuk lansia itu, sedangkan untuk pembiayaan awalnya pihak BIF hanya memberikan untuk 1 kelompok yaitu untuk 10 orang saja dengan jumlah pembiayaan yang telah ditentukan dari BIF. Pembiayaan Al-Qard yang diberikan dari pihak BIF kisaran 800.000 - 1.000.000/orang yang awalnya diberikan untuk 10 orang. Namun, yang membutuhkan pembiayaan di lingkungan Keprakan Lor RW 9 lebih dari 10 orang yaitu sebanyak 20-25 orang, maka total pembiayaan yang di peroleh harusnya untuk 10 orang dengan masing-masing memperoleh 800.000-1.000.000 jadi dibagi untuk 20-25 orang tadi dengan perolehan pembiayaan masing-masing orang mendapatkan 300.000-400.000. Dari pembiayaan Al-Qard yang diberikan dari pihak BMT BIF digunakan para ibu-ibu lansia untuk usaha-usaha kecil.

"... terus dari pihak BIF itu sebenarnya aku hanya diberi jatah 10 orang. Karena banyak orang gimana kita perlu pedulikan akhirnya saya ngerekrut 20-25 orang, haknya yang 10 orang tak suruh membagi ke 20 orang contonya BIF memberikan 800.000-1.000.000 untuk 10 orang terus aku meminta untuk 22 orang jadi ada yang 400.00 ada yang 300.00. Dari 20 orang itu ada yang bisnis ayam bacem, parsel, ada yang jualan buah musiman kelilinh, ada kelontong, ada yang agak keren jualan online shop karena punya anak kecil, ada yang sayuran, ada yang pakaian, sepatu rombeng, ada jagung bakar alunalun kidul terus ada yang angkringan terus saya kumpulkan orang-orang itu terus diberi modal sama alfikri . awalnya saya melunasi satu bulan terus dua dua bulan minjamnya, terus tiga bulan". (NA2)

Bentuk tanggung jawab sosial selanjutnya yang diberikan oleh BPRS BDW yang diberikan lebih secara langsung kepada masyarakat dan lingkungan sekitarnya. Kegiatan sosial yang dilakukan oleh BPRS BDW ada yang dilakukan secara rutin seperti kegiatan pemberian beasiswa yang diberikan kepada anak- anak pondok termasuk yang terakhir pada saat milad terakhir belum lama ini. Selain memberikan beasiswa pihak BDW adanya kegiatan bakti sosial yang diberikan disalah satu pondok pesantren yang ada di Bantul dan Wonosari, kegiatan-keggiatan tersebut dijalankan menggunakan dana ZIS yang dimiliki oleh BDW.

"Beasiswa itu rutin pada saat kita milad kita ada dari dana ZIS kita kemaren ke pondok di bantul dan wonosari kita bakti sosial disana".(B1)

\section{Mobilitas Sosial dan Ekonomi Nasabah LKMS}

Penerimaan pembiayaan dan bentuk kegiatan sosial akan sangat bermanfaat bagi masyarakat terutama bagi masyarakat yang membutuhkan maka akan sangat membantu. Pertama pada pembiayaan yang diberikan oleh BMT BIF salah satu nasabahnya memanfaatkan pembiayaan yang diberikan oleh BIF untuk membuka usaha rumahan yaitu usaha pembuatan nata de coco, usaha rumahan ini dibuat dengan menggunakan pembiayaan dari BIF berupa pembiayaan modal. Usaha tersebut sebulumnya belum di miliki oleh nasabah tersebut beliau memiliki ide untuk membuka usaha nata de coco ini namun belum memiliki modal untuk membuka usaha tersebut, dan akhirnya mengajukan pembiayaan ke pihak BIF.

"Sudah dari tahun 2005 karena untuk buka usaha saya mengawali memproduksi nata de coco, sebelumnya belum punya usaha baru mau merintis. Selain itu ada peningkatan produksi dengan melihat peningkatan jumlah awal nampan yang tadinya sekitar 700 sekarang menjadi sekitar 3000 nampan yang di gunakan untuk proses produksi". (NA1) 
Selain pembiayaan BIF juga memiliki program-program sosial dan pembiayaan sosial yang masuk dalam pembiayaan Al-Qard, kegiatan sosial yang di lakukan oleh BIF ada di beberapa daerah salah satunya di daerah Ledok Timoho dan daerah Keprakan Lor. BIF memiliki agenda sosial di kedua daerah tersebut yang sama yaitu kegiatan ngaji yang ditujukan untuk para ibu-ibu lansia terutama, kegiatan ini sangat bermanfaat bagi para ibuibu dengan adanya kegiatan ngaji ini para ibu-ibu mengetahui lebih dalam lagi sejarah Islam, cerita nabi, dan terjemahan dari surat-surat yang ada di Al-Qur'an, serta adanya kegiatan jalinan kasih yang di berikan BIF kepada para anak yatim piatu yang ada didaerah tersebut. Selanjutnya, untuk pembiayaan Al-Qard membantu para ibu-ibu lansia yang membutuhkan pembiayaan untuk membantu perekonomian mereka, pembiayaan Al-Qard ini salah satunya diberikan di daerah Keprakan Lor yang di manfaatkan oleh para ibu-ibu lansia untuk membuka usaha kecil-kecilan seperti berjualan baik keliling, dirumah, maupun ada yang berjualan melalui media online.

Kedua yaitu pembiayaan dan tanggung jawab sosial yang diberikan dari pihak BDW, pada pembiayaan yang diberikan BDW kepada nasabahnya sebagian besar pembiayaan tersebut di manfaatkan untuk usaha-usaha besar seperti pada kedua nasabah yang menjadi informan di penelitian ini. Pembiayaan yang diberikan kepada Nasabah 1 (NB1) di manfaatkan beliau untuk membuka usaha yang bergerak di bidang jasa pemasangan jaringan listrik, di mana NB1 sebelumnya memang sudah memiliki usaha namun terbatas dengan peralatan, modal, alat transportasi yang ada hingga akhirnya memilih untuk mengajukan pembiayaan ke pihak BDW yang digunakan untuk mengembangkan usahanya tersebut. Pengembangan usaha tersebut di lakukan dengan menambah peralatan dan kebutuhan pemasangan jaringan lainnya dengan mengambil pembiayaan modal kerja di BPRS BDW tersebut. Selain itu nasabah merasa tertolong dengan pembiayaan yang diberikan BDW, nasabah merasa tertolong termasuk dengan sistem bagi hasilnya yang sesuai. Kemudian, pada nasabah yang kedua jenis pembiayaan yang di ambil sama yaitu modal kerja dengan pembiayaan tersebut Nasabah 2 (NB2) menggunakan pembiayaan untuk usaha rental computer dan wartel pada awalnya yaitu pada tahun 2005. Pembiayaan diajukan untuk membeli peralatan-peralatan komputer dan wartel karena pada saat itu di mana wartel sangat banyak digunakan dan dibutuhkan oleh masyarkat, hingga akhirnya berganti dengan usaha jual beli mobil namun awalnya hanya 1-2 mobil yang dijual dengan mengikuti acara-acara penjualan mobil seperti yang di adakan setiap minggu di depan TVRI Jogja. Pembiayaan hingga saat ini masih berjalan dengan sistem Top Up yang diambil oleh NB2 dan usaha masih berjalan di bidang usaha jual beli mobil.

Dari beberapa hasil interview yang di lakukan kepada para nasabah dan anggota dari masing-masing lembaga keuangan tersebut relatif mengalami perubahan kearah yang lebih baik setelah mendapatkan pembiayaan dan menerima beberapa bentuk dan kegiatan sosial yang dilakukan kedua lembaga keuangan tersebut. Pada BMT BIF baik nasabah maupun anggota binaan menceritakan bagaimana usahanya dari awal di rintis dengan bantuan pembiayaan dari pihak BIF, pengawasan dan bimbingan yang diberikan oleh pihak BIF, pendampingan pada anggota binaan, dan kegiatan-kegiatan yang di berikan oleh BIF memberikan beberapa perubahan baik baik pada nasabah maupun anggota binaan hingga saat ini.

Pertama pada nasabah pembiayaan NA1 merasa BIF sangatlah membantu dalam beliau merintis usahanya dari awal, bahkan pada saat 2005 terjadi gempa usaha beliau mengalami kerugian dan usaha tidak bisa di jalankan karena peralatan sarana dan perasarana yang mengalami kerusakan. Pada saat itu pembiayaan yang di berikan BIF belum lunas sehingga beliau belum berani untuk mengajukan lagi, sehingga beliau memutuskan untuk mengajukan pembiayaan ke bank konvesional dan proses dari survai saja sudah 
membutuhkan waktu lama sedangkan beliau sudah membutuhkan usahanya tersebut untuk menjalankan kembali usahanya karena memang usaha tersebut menjadi salah satu usaha yang di miliki keluarganya. Pada akhinya NA1 memilih untuk mencoba mengajukan pembiayaan lagi ke BMT BIF dan dengan melihat dari faktor kerugian yang terjadi dan berbagai pertimbangan pembiayaan diberikan kembali oleh BIF kepada NA1, hingga saat ini usaha tersebut masih berjalan dan berkembang dengan baik dengan melihat dari jumlah nampan yang bertambah pada tahun 2005 berjumlah 700 nampan sekarang 3000-an nampan dan jumlah penjualan kepengepul semakin banyak.

“... untuk prosesnya dan persyaratannya tidak rumit lebih sederhana, dulu saya pernah mencoba di bank konvensional walaupun tidak rumit juga pinjam kok lama pengajuan saja lama terus sudah itu tunggu proses mau survainya lama padahal kan saya segera butuh kan karena terjadi gempa akhirnya saya ambil TOP UP kan soalnya saya dulu masih punya pinjaman jadi kan saya milih ke bank tapi kok lama saya segera dibutuh untuk proses produksi lagi tapi lama ya akhirnya saya ke BMT lagi, nampannya saja pada pecah terus saya tanya seandainya mau pinjam lagi padahal saya kan belum lunas. Lalu saya mengajukan kesini lagi TOP UP mungkin karena ada gempa itu bukan karena manusia terus realistis gitu. Untuk bidang usaha itu ada perubahan ya dari awal tidak punya usaha terus punya usaha itu 1, kalau selama perjalannya karena akadnya murabahah sudah di sepakaati diawal harganya berapa kesepakatanya berapa untuk modal kerja untuk angsurannya itu diangsur jadi manfaatnya ya bisa mendukung proses produksi dan pengembangan usaha yang tadinya tidak ada hasil jadi ada hasil". (NA1)

Selanjutnya yaitu pada nasabah BPRS BDW, NB1 juga merasa terbantu dengan pembiayaan yang diberikan oleh BPRS BDW dimana pada saat awal usahanya hanya usaha kecil dengan peralatan yang terbatas SDM hanya 4 orang serta mobil hanya 1, sedangkan untuk menjalanjakan usaha di bidang tersebut dengan perlatan, sdm, alat transportasi yang terbatas maka akan sulit untuk berkembang dengan pembiayaan yang diberikan BPRS BDW dan pembiayan berlanjut hingga saat ini dengan system TOP UP sekarang usaha tersebut sudah berbeda jauh, usaha semakin berkembang dengan jumlah SDM meningkat menjadi 12 orang, mobil dan kren berjumlah 3 unit, peralatan yang semakin memadai dan tentunya penghasilan yang sudah meningkat jauh.

\section{Pelaporan Tanggung Jawab Sosial}

Kegiatan ataupun program yang telah dijalankan oleh lembaga keuangan biasanya pada akhir dibuat pelaporan baik itu kegiatan berkaitan dengan keuangan yaitu Laporan Keuangan dan kegiatan diluar kegiatan keuangan (Maali, 2006). Kegiatan non keuangan antara lain seperti kegiatan sosial baik di internal lembaga keuangan itu sendiri maupun dari pihak lembaga keuangan kepada masyarakat baik kegiatan yang secara langsung di ikuti oleh pihak lembaga keuangan tersebut maupun tidak secara langsung seperti sponsorship. Pertama, pada BMT Bina Ikhsanul Fikri dengan berbagai kegiatan dan program sosial yang dilakukan kepada masyarakat ataupun nasabahnya terutama, BIF melaporkan segala kegiatannya setiap tahunnya dalam buku rapat anggota tahunan yang dimiliki. Pada buku RAT setiap tahunnya berisi Rencana Program Kerja Tahun tersebut, Realisasi Program Kerja, dan Rencana Program Kerja Tahun Berikutnya.

Dalam Pelaporan Realisasi di dalamnya berisi 7 Bidang yang terdiri dari Bidang Organisasi dan Kepengaruhan, Bidang Usaha berkaitan dengan pengembangan usaha lembaga keuangan tersebut, Bidang Administrasi, Bidang Pemasaran, Bidang Pengendalian Internal, Bidang Pengembangan SDI, Bidang Keanggotaan, dan Bidang Baitul Maal, serta 
adanya pelaporan keuangan. Terkait dengan pelaporan keuangan, produk dan pelayanan pembiayaan, Pengembangan SDI, Kegiatan Sosial, Corporate Governance, dan adanya pelaporan hasil pengawasan manajemen sebagian besar telah dilaporkan dengan baik oleh BMT BIF. Pelaporan BMT BIF yang telah dibuat selama ini sudah dilaporkan dengan sangat terstruktur dari susunan pelaporan mulai dari Internal BIF sendiri hingga kegiatan sosial yang diberikan kepada masyarakat yang masuk dalam Bidang Baitul Maal, pelaporan yang di buat oleh BMT BIF setiap tahunnya mengalami perbaikan dari segi bentuk pelaporannya. Dalam pelaporan yang di miliki BIF terkait dengan kegiatan-kegiatan ataupun program sosial yang dijalankan BIF masuk dalam bidang Baitul Maal seperti program pengembangan kelompok dampingan untuk usaha produktif, Pendirian Pesantren Wira Usaha Al Maun, Pendirian Panti Asuhan Al Amin, pengembangan wakaf tunai dan zakat produktif, Pendampingan Desa Binaan dan masih banyak kegiatan-kegiatan sosial yang dilakukan oleh BMT BIF. Selain itu pelaporan keuangan BMT BIF termasuk pelaporan pembiayaan berdasarkan akad telah dilaporkan beserta grafik presentase tingkat pemberian pembiaayaan berdasarkan akadnya. Kegiatan sosial ini juga diakui oleh salah satu anggota binaan yang bertempat tinggal disekitar panti asuhan yang menjadi salah panti asuhan yang menerima santunan yaitu "jalinan kasih".

Kedua, yaitu pada BPRS BDW yang mana lembaga ini juga memiliki kegiatan-kegiatan sosial yang diberikan kepada para masyarakat dan lingkungan sekitarnya. Kegiatan sosial yang dilakukan oleh BPRS BDW dilakukan lebih banyak bersifat fleksibel artinya kegiatan yang dilakukan tidak menentu dilakukan dalam kegiatan apa atau bagaimana kegiatan itu dijalankan. Kegiatan sosial dilakukan hanya pada saat acara tertentu seperti Milad, pemberian santunan, sponsorship untuk lembaga baik pendidikan maupun non pendidikan yang membutuhkan dana tambahan dalam berjalannya suatu kegiatan, dan lain lain. Namun, di BPRS BDW kegiatan-kegiatan tersebut belum dilaporkan dalam suatu laporan baik dalam laporan tahunan maupun laporan-laporan lainnya yang dimiliki BDW. Pembuatan laporan hanya berbentuk laporan pertanggung jawaban (LPJ) yang dibuat panitia kegiatan sosial tersebut yang diberikan kepada direksi, selebihnya tidak ada pelaporan mengenai kegiatan tangung jawab sosial tersebut.

\section{Tingkat Kesesuaian Pelaporan}

Pelaporan merupakan suatu hal yang penting bagi sebuah lembaga terutama lembaga keuangan dimana pihak penanam saham maupun para anggota akan membutuhkan laporan sebagai salah satu bahan pertimbangan, yang tentunya juga akan menarik minat maupun keinginan para penanam saham maupun anggota lembaga keuangan tersebut untuk memberikan dananya sebagai bentuk investasi ke lembaga keaungan tersebut terutama laporan yang menunjukan bahwa lembaga keuangan tersebut dalam kondisi baik dan memiliki berbagai kegiatan yang positif. Pada lembaga keuangan BMT Bina Ihsanul Fikri menunjukan pelaporan yang dibuat baik dari berbagai aspek yang ada pada Islamic Social Reporting BIF telah memenuhi tingkat kesesuaian ISR dari beberapa aspek sepeti Pembiayaan dengan akad BIF telah menggunakan beberapa pembiayaan dengan akad yang sesuai dengan syariah dan melaporkannya.

Sebagian besar tingkat pelaporan ISR sudah tinggi sesuai dengan indeks ISR yang ada dan kegiatan serta pelaporan yang ada relatif dilakukan secara rutin dan konsisten dalam setiap tahunnya, sebagai contoh kegiatan Wakaf dalam setiap tahunnya BMT BIF telah melakukan kegiatan tersebut dan melaporkannya secara rutin dan konsisten yaitu pada tahun 2013, 2014, dan 2015 kegiatan ini dilakukan oleh BMT BIF dan dilaporkan dengan baik. Dari lembar pengungkapan sesuai indeks ISR tahun 2013 telah terpenuhi sebanyak 32 item, tahun 201434 item terpenuhi, dan tahun 201536 item telah terpenuhi. Selain itu kegiatan-

$$
\text { Jati : Jurnal Akuntansi Terapan Indonesia, } 2020 \text { | } 51
$$


kegiatan berkaitan dengan kegiatan sosial atau lebih disebut Baitul Maal dalam BMT BIF seperti pendirian lembaga sosial/pendidikan Islam yang dilakukan setiap tahunnya dan dilaporkan bagaimana kegiatan tersebut dilakukan. Sebagian besar pada BMT BIF Indeks ISR telah terpenuhi dengan menjalankan kegiatan- kegiatan yang sesuai dengan Syariah dan menghindari kegiatan transaksi keuangan yang dilarang oleh syariah seperti penarikan bunga, manipulasi, kegiatan penipuan dan lain lain. Selain itu, pelaporan telah dibuat sesuai dengan kegiatan yang dilaksanakan dengan baik.

Pelaporan yang dilakukan BMT BIF tidak hanya dilaporkan dalam RAT dalam bentuk buku, namun pelaporan juga dilakukan melalui website BMT BIF (bmt-bif.co.id). Namun dalam website tidak dilaporkan secara lengkap tidak seperti pada pelaporan RAT dan pelaporan yang terakhir belum di Update pada tahun 2015 belum dilaporkan di website resmi BMT BIF. Pelaporan yang disajikan diwebsite BMT BIF seperti agenda bakti sosial, pelatihan BMT BIF, pelatihan ke BMT-an, produk yang disediakan, distribusi bagi hasil dan lain lain. Sedangkan pada BPRS untuk laporan keuangan dan pelaporan mengenai pembiayaan yang sesuai dengan ketentuan syariah telah dilaporkan dengan cukup baik, namun pelaporan untuk kegiatan sosial maupun pengembangan SDI tidak ada laporan yang dibuat, hanya sebatas pelaporan yang dibuat oleh internal BDW kepada direksi belum adanya pelaporan sosial sesuai dengan ISR yang dibuat oleh BPRS BDW, akan tetapi dari hasil penelitian yang dilakukan bagian pelaporan mengatakan kedepannya mungkin akan dapat menerapkan pelaporan sesuai dengan indeks ISR tersebut.

Pelaporan yang dilakukan oleh BPRS BDW dipublikasikan oleh Otoritas Jasa Keuangan karena memang BDW dibawah naungan OJK, pelaporan publikasi triwulan yang dimiliki oleh BDW berisi pelaporan keungan, kepemilikan bank, dan pengurus bank (pemegang saham), laba rugi, bagi hasil, pelaporan sebatas pada kepentingan pelaporan untuk para pemegang sahamnya. Dari wawancara dengan bagian pelaporan BPRS BDW memang pelaporan berlandaskan pada peraturan yang ada di OJK. Dari hasil lembar pengungkapan indeks ISR 23 item telah terpenuhi, masih terdapat beberapa indeks yang belum terpenuhi seperti kegiatan-kegiatan sosialnya. Namun sebenarnya kegiatan-kegiatan tersebut telah dilakukan oleh BDW seperti pemberian beasiswa, sponsorship, sadaqah, wakaf, santunan anak yatim dan kegiatan sosial lainnya. Pelaporan yang dilakukan oleh BPRS BDW tidak hanya yang terdapat pada laporan publikasi triwulan di OJK, namun terdapat pelaporan di website resmi BPRS BDW (www.bprs-bdw.co.id) seperti pelaporan bagi hasil, produk dan jasa, laporan tahunan, dan lembaga- lembaga yang bekerja sama dengan Bangun Drajat Warga.

\section{KESIMPULAN}

Hasil penelitian yang didapat bahwa tata kelola kedua lembaga keuangan syariah yang diteiliti telah mengupayakan untuk mendukung pergerakan mobilitas sosial ekonomi nasabah. Bentuk bentuk tanggung jawab sosial yang dilakukan oleh kedua LKMS tersebut relatif sama, namun cara melakukannya memiliki cara tersendiri yaitu secara langsung maupun secara tidak langsung. Dalam hal pelaporan kegiatan sosial di kedua lembaga keuangan ini terdapat beberape perbedaan. Pada BMT BIF pelaporan kegaitan sosial dilaporkan secara keseluruhan dan masuk pada bidang Baitul Maal BMT BIF dan dilaporkan dalam laporan RAT setiap tahun bersama dengan laporan-laporan lain seperti laporan keuangan BIF, laporan hasil pengawasan manajemen, dan syariah serta laporan-laporan lain, sedangkan pada BDW hanya sebatas laporan keuangan dan kepimilikan saham.

Dari pembiayaan dan kegiatan sosial yang dilakukan kedua lembaga tersebut, penerima pembiayaan yang sudah merasakan langsung manfaat dari mereka mendapatkan 
pembiayaan, menunjukan bahwa sebagian besar dari adanya pembiayaan yang diberikan dari LKMS sangat membantu terutama dalam peningkatan pendapatan dari yang sebelumnya tidak memiliki usaha hingga memiliki usaha dan merubah tingkat pendapatan mereka, membatu mengembangkan usaha yang tentunya meningkatkan pendapatan mereka, dan terbebas dari rentenir, dari beberapa hal diatas menunjukan adanya perubahan baik aspek sosial maupun ekonomi yang terjadi dimasyarkat kearah yang lebih baik. Berdasarkan penelitian ini dapat dikatakan tata kelola LKMS telah secara efektif membantu pergerakan mobilitas di masyarakat

Dalam hal kesesuaian pelaporan, BMT BIF tampak lebih lengkap dibanding dan BPRS BDW. Pada BMT BIF lebih dari $70 \%-80 \%$ indeks ISR telah terpenuhi. Pelaporan sosial telah dilaporkan terperinci adanya pelaporan program baitul maal yang akan di kerjakan tahun tersebut dan adanya pelaporan realisasinya. Sedangkan pada BPRS BDW $50 \%$ telah terpenuhi namun pelaporan kegiatan sosial belum dilakukan karena kegiatan sosial di BDW hanya dilaporkan dalam laporan pertanggung jawaban yang diserahkan kepada bagian direksi. Praktik ini dikarenakan BPRS BDW melakukan pelaporan berlandaskan pada aturan yang ada pada Otoritas Jasa Keuangan karena BPRS BDW berada dibawah naungan Otoritas jasa keuangan.

Penelitian ini hanya menggunakan 2 lembaga mikro syariah sebagai objek penelitian yaitu BMT BIF dan BPRS BDW, sehingga hasil penelitian belum mencakup secara umum yang mewakili LKMS di Yogyakarta. Untuk penelitian selanjutnya disarankan untuk dapat terfokus pada satu jenis LKMS yang tersebar di Yogyakarta namun dengan jumlah objek yang lebih banyak. Jika dilakukan secara kualitatif, perlu memperluas informan dengan menambahkan bagian pelaporan dan dewan pengawas Syariah. Penelitian yang akan datang disarankan untuk menggunakan pendekatan kuantitatif dengan kuesioner untuk melihat berapa persentase manfaat pembiayaan yang diterima nasabah.

\section{DAFTAR PUSTAKA}

Baskara, IGK, 2013, "Lembaga Keuangan Mikro di Indonesia”, Jurnal Buletin studi Ekonomi, Vol.18, No.2.

Badan Pusat Statistik (2017), Kemiskinan di Daerah Istimewa Yogyakarta. https://yogyakarta.bps.go.id/subject/23/kemiskinan.html\#subjekViewTab4

Buchori, A., 2003, "Kajian Kinerja Industri BPRS di Indonesia”, Buletin Ekonomi Moneter dan perbankan.

Erwanda, Edwin, 2012, "Tanggung Jawab Sosial pada organisasi perbankan Syariah", Jurnal Akuntansi Universitas Brawijaya.

Finarti, A \& Purnama, P. 2015, "Implementasi Maqasid al-Syariah Terhadap Pelaksanaan CSR Bank Islam", ICOSOPP.

Fitria \& Hartanti, 2010, "Islam Tnggung Jawab Sosial : Studi perbandingan pengungkapan GRI da ISR”. Simposium Pendidikan Nasional Akuntansi XIII Purwokerto. Universitas Jendral Soedirman.

Hardi, A. E., 2013, “Analisis Pemberdayaan Masyarakat Miskin melalui Qardlu Hasan”, Alumni Pasca Sarjana UGM.

Ibrahim, 2015, "Metodologi Penelitian Kualitatif", Alfabeta

Junaidi, 2015, "Analisis Pengungkapan CSR Perbankan Syariah di Indonesia Berdasarkan Islamic Social Reporting Index”, Jurnal Akuntansi dan Investasi, Vol. 16 No.1.

Khoirudin, A., 2013, "Corporate Governance dan pengungkapan Islamic Social Reporting pada perbankan Syariah di Indonesia”, Jurnal Unnes, ISSN 2252-6765.

Latif, S., 2016, "Pengaruh Mobilitas Sosial terhadap Perubahan Bahasa" Jurnal Pendidikan ISSN 1693-4164, Vol. 14 No 1

Jati : Jurnal Akuntansi Terapan Indonesia, 2020 
Moleong, L, 2006, "Metode Penelitian Kualitatif", Bandung, Remaja Rosda Karya, Edisi Revisi.

Maali, B., 2006, "Social Reporting by Islamic Banks", ABACUS, Vol.42, No.2.

Othman, T., 2010, "Islamic Social Reporting Of Listed Companies In Malaysia", International Business \& Economics Research Journal, Vol 9, Number 4.

Rasid, A, 2017, Sekilas tentang lembaga keuangan mikro syariah di Indonesia” https://businesslaw.binus.ac.id/2017/03/31/sekilas-tentang-lembaga-keuangan-mikro-syariah-di-indonesia/ diakses 23 Juni 2020.

Republika, 2014, OJK Inventarisir Lembaga Keuangan Mikro, https://republika.co.id/berita/ngdjoz/ojk-inventarisir-lembaga-keuangan-mikro.

Wahyuni Sri, 2015, "Studi Tentang Mobilitas Ekonomi Masyarakat Petani Cengkeh di Desa Lingadan Kecamatan Dakopemean Kabupaten Tolitoli” Pendidikan Geografi, Universitas Tadulako.

Yaya, R., Martawireja, A., dan Abdurahim, A. 2013. Akuntansi Perbankan Syariah: Teori dan Praktek Kontemporer. Salemba Empat, Jakarta

Yusuf, S.D., 2014, "Peran Strategis Baitul Maal Wat Tamwil (BMT) dalam peningkatan Ekonomi Rakyat”, Jurnal Al-Mizan. Vol. 10 Nomor 1.

Zuraya, N. 2016, "Lembaga Keuangan Mikro Syariah Bisa Tingkatkan Ekonomi Masayarakat Miskin”, Republika.co.id, 2016, diakses pada Selasa 26 Desember 2016 jam 8.32 WIB. www. BMT-BIF.co.id

www. BPRS BDS.co.id www. OJK.co.id 